Bull. Iraq nat. Hist. Mus.

http://dx.doi.org/10.26842/binhm.7.2018.15.2.0153

December, (2018) 15 (2): 153-16

\title{
A NEW RECORD OF COELASTRELLA TERRESTRIS (REISIGL) HEGEWALD \& N. HANAGATA, 2002 (SPHAEROPLEALES, SCENEDESMACEAE) IN IRAQ
}

\author{
Altaf Al-Rawi Bushra M. J. Alwash Nagham E. Al-Essa \\ and \\ Fikrat M. Hassan* \\ Department of Biology, College of Science for Women, University of \\ Baghdad, Baghdad, Iraq \\ *Corresponding Author: fikrat@csw.uobaghdad.edu.iq
}

Received Date: 1 June 2018

Accepted Date: 6 August 2018

\begin{abstract}
This study identified the genus Coelastrella Chodat, 1922 which was isolated from a sediment sample taken from the Tigris river in Baghdad Governorate, Iraq. The alga was isolated and cultured in modified Chu 10 media and the morphological features of the isolated algae were observed in light microscopy (LM); it showed some characteristic features of this genus, such as its ellipsoidal or lemon- shaped cells, a visible pyrenoid and the chloroplast parietal. To ensure correct identification of the isolated alga, a molecular analysis using $18 \mathrm{~S}$ $r R N A$ gene and DNA sequencing revealed a match with $C$. terrestris (Reisigl) Hedewald \& N. Hanagata 2002. This species is a new record in Iraq, and has been registered in NCBI under the accession number MH179121.
\end{abstract}

Keywords: Coelastrella terrestris, Iraq, MH179121, NCBI, Scenedesmaceae.

\section{INTRODUCTION}

The classification of algae based on morphological and ultrastructural approaches has been performed for a long time (Prescott, 1973, Graham and Wilcox, 2000, Wehr and Sheath, 2003) while molecular approach is using the sequences of small and large subunits of ribosomal RNA genes. Therefore, most of coccoid green algae such as Chlorella (Beyerinck) have been revised and most of these alga changed into a new genus such as the Chlorella fusca var. vacuolata which is basionym of Coelastrella vacuolata (Hegewald and Hanagata, 2002).

Chodat first described Coelastrella in 1922(Chodat, 1922); Uzunov et al. (2008) explained the historical classification of $C$. terrestris according to its morphology under a light microscope and scanning electron microscopy. Tschaikner et al. (2008) mentioned that the genera Scotiellopsis Vinatzer or Graesiella Kalina et Punčoch were registered as Coelastrella according to the study of Hegewald and Hanagata (2000, 2002).

The basionym of $C$. terrestris is Scotiellaterrestris Reisigl, and this algae is within the subfamily Scendesmodeae (Hegewalid and Hanagata, 2002); many studies isolated the $C$. terrestrial from the surface of the rock (Aburai et al., 2013) or from soil in Bulgaria (Uzunov et al., 2008) and some other Coelastrella spp. was isolated from alpine in Austria (Tschaikner et al., 2007 and 2008). This genus has a distinctive cell wall with ribs, its cell 


\section{A new record of Coelastrella terrestris}

form, chloroplast and pyrenoid (Tschaikner et al., 2007); Uzunov et al. (2008) revealed the difficulty to observe the ribs by light microscope examination, but they can be visible (ribs are about 8-14 in number) when using a scanning electron microscope (SEM); many authors revealed the importance of Coelastrella spp., because they contain antioxidants and other commercial compounds (Vilchez et al., 2011; Aburai et al., 2013). The C. terrestrial belongs to Coelastroideae (subfamily), Scenedsmaceae (family), Sphaeropleales (order) and Chlorophyceae (class) (Guiry, 2018).

Many authors in Iraq investigated aquatic algae, including phytoplankton, benthic algae and macroalgae (Maulood et al., 2013); A few of them studied soil algae collected from the rice-fields in Iraq (Al-Kaisi, 1976; Al Mousawi and Whitton, 1983), but there are few studies up to date on terrestrial algae. Maulood et al. (2013) listed 788 taxa of Chlorophyceae in Iraq, but without mentioning the genus Coelastrella Chodat; only one recent study reported Coelastrella as isolated from Tigris river by using $18 S \mathrm{rRNA}$, but the study did not classify its species (Abed et al., 2018).

This study aimed to confirm the identification of the species of Coelastrella by using molecular analysis and it is an attempt to revise the classification of Iraqi algal flora by this technique.

\section{MATERIALS AND METHODS}

The algae sampling and culture condition:

The algae was collected from sediments on the bank of the Tigris river during autumn 2017; the sediment sample was collected at a depth of $2-3 \mathrm{~cm}$ with an area of $50 \mathrm{~m}^{2}$ below the sediment surface by spatula and kept in a nylon sac with some river water (Hassan et al., 2017).

A liquid solution was prepared from the sediment sample by mixing 1 part of sediment with 2 parts of distilled water. The alga was inoculated into modified Chu-10 nutrient solution (Tab. 1), following the steps described by Hassan et al. (2013). These cultures were incubated in a cooled illuminated incubator with $30 \pm 3^{\circ} \mathrm{C}, 300 \mu \mathrm{E} / \mathrm{m} 2 / \mathrm{s}$ and $16: 8$ light: dark for 20 days in the Advance Algal Laboratory of the Department of Biology, College of Science for Women at the University of Baghdad. Microscopic examination was done by Genex compound microscope model GX- 140105 . 
Altaf Al-Rawi et al.

Table (1): Modified Chu 10 medium composition (followed Hassan et al., 2013)

\begin{tabular}{ccc}
\hline $\begin{array}{c}\text { Number of stock } \\
\text { solution }\end{array}$ & $\begin{array}{c}\text { Chemical formula of each } \\
\text { salt }\end{array}$ & Concentration g/l \\
\hline 1 & $\mathrm{MgSO} 4$ & 10 \\
2 & $\mathrm{~K} 2 \mathrm{HPO} 4$ & 4 \\
3 & $\mathrm{NaNO} 3$ & 8 \\
& $\mathrm{CaCl} 2$ & 16 \\
4 & $\mathrm{Fe} \mathrm{Cl} 3$ & 0.32 \\
5 & $\mathrm{EDTA}-\mathrm{Na} 2$ & 4 \\
6 & $\mathrm{NaCl}$ & 30 \\
7 & $\mathrm{Na} 2 \mathrm{CO} 3$ & 8 \\
8 & $\mathrm{MnCl} 2.4 \mathrm{H} 2 \mathrm{O}$ & 0.02 \\
& $(\mathrm{NH} 4) 6 \mathrm{Mo} 7 \mathrm{O} 24.4 \mathrm{H} 2 \mathrm{O}$ & 0.028 \\
& $\mathrm{ZnSO} 4.7 \mathrm{H} 2 \mathrm{O}$ & 0.224 \\
& $\mathrm{CuSO} 4.5 \mathrm{H} 2 \mathrm{O}$ & 0.08 \\
& $\mathrm{COCl} 2.6 \mathrm{H} 2 \mathrm{O}$ & 0.0004 \\
& $\mathrm{H} 3 \mathrm{BO} 3$ & 0.288 \\
9 & $\mathrm{Na} 2 \mathrm{SiO} 3$ & 5.7 \\
\hline
\end{tabular}

\section{Identification of samples using molecular method:}

Primer selection :

The isolated microalgae was identified by the amplification of conserved $18 \mathrm{~S}$ rRNA encoding gene using ITS1 and ITS4 universal primers (Vorobyev et al., 2009). A forward primer (5'-TCCGTAGGTGAACCTGCGG-3') and a reverse primer $\left(5^{\prime}\right.$ TCCTCCGCTTATTGATATGC-3') were used; primers set supplied by IDT (Integrated DNA Technologies company, Canada).

\section{Genomic DNA extraction:}

The genomic DNA of algae was extracted by using a fast DNA Intron kit (G-spin Total DNA Extraction) and the isolated DNA was subjected to PCR (Gene Amp, PCR system 9700; Applied Biosystem) according to manufacturer's instructions. The PCR products were separated by $1 \%$ agrose gel electrophoresis and visualized by ultraviolet light $(302 \mathrm{~nm})$.

\section{Polymerase chain reaction $(\mathbf{P C R})$}

The PCR amplification reaction was performed in a total volume of $25 \mu 1$ containing $2 \mathrm{ng} / \mu \mathrm{l}$ DNA, (1 X) Taq PCR PreMix (Intron, Korea), and $1 \mu \mathrm{M}$ of each primer, and then distilled water was added into tubes. The thermal cycling conditions were performed as follows: Denaturation at $94{ }^{\circ} \mathrm{C}$ for $3 \mathrm{~min}$, followed by 35 cycles of $94^{\circ} \mathrm{C}$ for $45 \mathrm{~s}, 52^{\circ} \mathrm{C}$ for $1 \mathrm{~min}$ and $72^{\circ} \mathrm{C}$ for 1 min with final incubation at $72^{\circ} \mathrm{C}$ for 7 min using a thermal Cycler (Gene Amp, PCR system 9700; Applied Biosystem). The PCR products were separated by $2 \%$ agarose gel electrophoresis and visualized by exposure to ultraviolet light $(302 \mathrm{~nm})$ after red stain staining (Intron Korea). 


\section{A new record of Coelastrella terrestris}

\section{Sequencing and data analysis}

Sequencing of $18 S$ rRNA gene was performed by the national instrumentation center for environmental management (nicem) online at:

http://nicem.snu.ac.kr/main/?en_skin=index.html, using a DNA sequencer 3730XL by Applied Biosystem. A homology search was conducted using Basic Local Alignment Search Tool (BLAST) program which is available at the National Center Biotechnology Information (NCBI) online at (http:// www.ncbi.nlm.nih.gov) and the BioEdit program. An expected value is defined to give an estimate of the number of times expected to get the same similarity coincidental and the lower the value of $\mathrm{E}$. This indicates that the degree of similarity was high between sequences which give greater confidence; a value close to zero means that these sequences are identical and the Bit Score, which is a statistical measure of the sequence similarity and the higher value indicates a high degree of similarity. The phylogenetic tree of aligned sequences was conducted using MEGA 6 program.

\section{RESULTS AND DISCUSSION}

The examination of the isolated green algae under the compound microscope appeared as ellipsoidal or lemon-shaped cells; it is a broad ranged, with a width of $7.2 \mu \mathrm{m}$ to $8.4 \mu \mathrm{m}$ and length $9.8 \mu \mathrm{m}$ to $10.8 \mu \mathrm{m}$. Other morphological features observed a visible pyrenoid and the chloroplast parietal, but the ribs on the cell were not seen in this investigation. Also, the autospores of the algae was observed and appeared as clusters of two or four (Pl. 1); many authors showed that the ribs of this species were hardly visible under the light microscope, but appeared clearly by using SEM (Uzunov et al., 2008). Prescott (1973) reported that Chlorella was confused with other soil algae or subaerial genus due to its cell ellipsoid $(7-8 \mu$ in diameter and $9.5 \mu$ ) and produce $4-8$ autospores. Therefore, it is important to use the molecular analysis for the algal classification to raise the ambiguity of the classification according to the observed morphology.

Many related genera of the coccid algae has been rearranged according to the use of molecular concept which included the $C$. terrestris (Hanagata, 1998; Hegewald and Hanagata, 2002). In this study, the LM and molecular approach used to identify the C. terrestris.

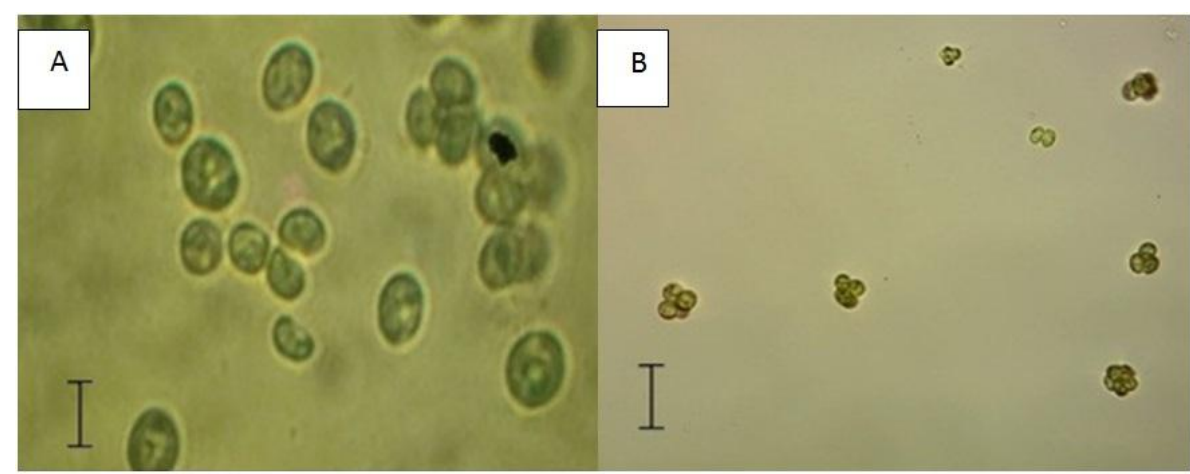

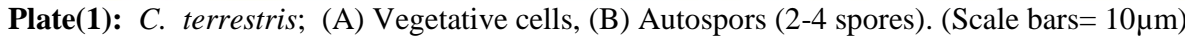

Identification of the microalga $C$. terrestris was confirmed by sequence-based phylogenetic analysis using $18 S$ ribosomal RNA gene sequencing; the PCR products obtained were subsequently sequenced to obtain DNA sequences, and a 650 base pair product was obtained (Pl. 2). The amplicon was aligned using BLAST at NCBI, the $18 S r R N A$ sequence of isolated 


\section{Altaf Al-Rawi et al.}

alga showed $95 \%$ homology with the existing NCBI database sequence of $C$. terrestris with accession number JX5513888.1. This isolate was identified as C. terrestris, an 18S rRNA encoding genomic sequence was submitted to NCBI and registered under accession number MH179121. A dendogram was used to depict $18 S$ rRNA sequence similarity between algal sequence detected in our study and those of related algal organisms at NCBI (Dig.1).The nucleotide sequence of the JX513 888.1 of $C$. terrestris recorded in Czech Republic (Trenkwalder, 1975) was very similar to that of the recorded algae aligned in this study with 95\% similarity and also with the other two groups of the same species that recorded in NCBI in Russia and Japan.

Scotiellaopsis terrestris and S. oocystiformis were changed to Coelastrella according to the study of Hegewald and Hanagata (2002). Their study, based on 18S RNA analysis, resolves and corroborates the classification according to morphological features. The algae $\mathrm{C}$. terrestris is found in terrestrial habitats, but might be found occasionally in other habitats (Tschaikner et al., 2007). In the current study the alga $C$. terrestris was found in the sediment sample of the Tigris River; its presence in river sediment might be accidental due to soil erosion from the surrounding river areas due to the rain action.

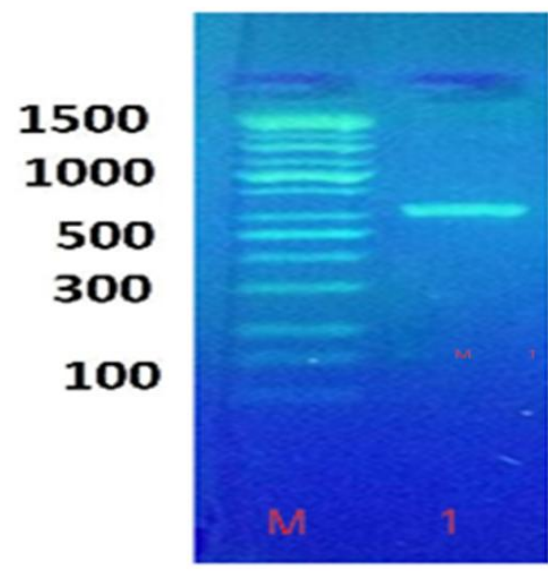

Plate (2): Amplified PCR product of band size 650bp. Lane 1: the product was electrophoresis on $2 \%$ agarose at 5 volt $/ \mathrm{cm}^{2}$ with $1 \mathrm{x}$ TBE buffer for 1:30 hours. Lane M: DNA ladder (100), visualized under U.V light. 
A new record of Coelastrella terrestris

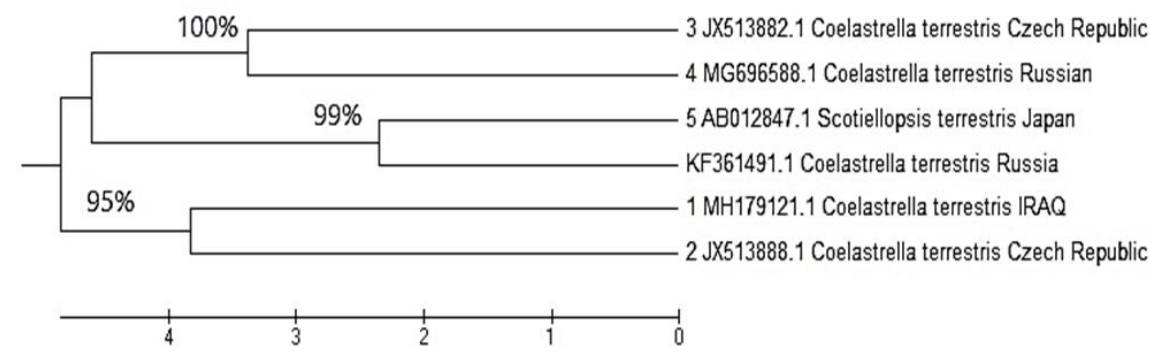

Diagram (1): Phylogenetic tree of Coelastrella terrestris based on 18S rRNA gene sequences conferred by GeneBank data base, aligned together with algae available in the NCBI were analyzed and aligned through BLAST from NCBI using the Neighbor-Joining Analyses of 532 bp of corresponding position of $18 \mathrm{~S} r R N A$ gene sequence. MEGA 6 program was used for phylogenetic tree.

The identification of the alga $C$. terrestris is for the first time it was recorded in Iraq, which may lead one to think there is a misidentification of this algae due to its ambiguous morphology. However, the additional molecular analysis leads to a conclusion which is difficult to refute.

\section{ACKNOWLEDGEMENTS}

The authors thank Dr. Jinan S. Al-Hassany, Dr. Safaa AL-Deen A. Al-Qaysi and Halah Al Haideri for their comments on the results.

\section{LITERURE CITED}

Abed, I. J., Abdulhasan, G. A. and Najem, A. M. 2018. Genotype versus phenotype to determine the definitive identification of the genera Chlorella Beijrinck, 1890 (Chlorophyceae) and Coelastrella Chodat, 1922 (Scendesmaceae). Bulletin of Iraq Natural History Museum, 15(1): 101-111.

Aburai, N., Ohkubo, S., Miyashita, H. and Abe, K. 2013. Composition of carotenoids and identification of aerial microalgae isolated from the surface of rocks in mountainous districts of Japan. Algal Research, 2(3): 237-243. https://doi.org/10.1016/j.algal.2013.03.001

Al- Kaisi, K. A. 1976. Contribution to the algae flora of the rice fields of south Eastern Iraq. Nova Hedwigia, 27: 813-827.

Al-Mousawi, A. H. A. and Whitton, B. A. 1983. Influence of environmental factors on algae in rice-field soil from the Iraqi marshes. Arabian Journal of Gulf Research, 1(1): 237-253.

Chodate, R. 1922. Materials for the history of the Swans of Switzerland, I-IX. Bullet in the Botanical Scientist of Geneva, 13: 66-114.

Graham, L. E. and Wilcox, L. W. 2000. Algae. Prentice Hall: Upper Saddle River, N. J., 640 pp. 


\section{Altaf Al-Rawi et al.}

Guiry, G. M. 2018. AlgaeBase. World-wide electronic publication, National University of Ireland, Galway. Available at: http://www.algaebase.org; (Accessed 6 May 2018).

Hassan, F. M., Aljbory, I. F. and Jumaily, E. F. A. 2013. Stimulation of biodiesel production from two algae: Chlorella vulgaris Berjerinck and Nitzschia palea (Kütz.) Smith, and study their some growth parameters under different light intensity. IOSR Journal of Environmental Science, Toxicology and Food Technology (IOSR-JESTFT), 6(2): 3142.

Hassan, F. M., Salman, J. M. and Al-Nasrawi, S. 2017. Community structure of benthic algae in a lotic ecosystem, Karbala Province-Iraq. Baghdad Science Journal, 14(4): 692-706. doi: 10.21123/bsj.2017.14.4.0692.

Hanagata, N. 1998. Phylogeny of the subfamily Scotiellocystoidae (Chlotophyceae, Chlorophyta) and related taxa inferred from $18 \mathrm{~S}$ ribosomal RNA gene sequence data. Journal of Phycology, 34:1049-1054.

Hegewald, E. and Hanagata, N. 2000. Phylogenetic studies on Scenedesmaceae (Chlotophyta). Archiv Für Hydrobiologie, Suppl. 136 (Algological Studies), 100: 29-49.

Hegewald, E. and Hanagata, N. 2002. Validation of the new combinations of Coelastrella and Neodesmus and the description of the new subfamily Desmodesmoideae of the Scendesmaceae (Chlorophyta). Archiv fur Hydrobiologie, Supplement 143 (Algological Studies 105): 7-9.

Maulood, B. K., Hassan, F. M., Al- Lami, A. A., Toma, J. J. and Ismail, A. M. 2013. Checklist of algal flora in Iraq. Ministry of Environment, 94pp.

Prescott, G. W. 1973. Algae the Western Great Area. William, C., Brow, Co., Publishers Dubugue, Lowa, 977pp.

Trenkwalder, H. 1975. Studies on the soil algae floraVarious types of forest foals in the area of Bressanone(Siidfirollltalien). Dissertation Philosophy Fakulaten Univrsity. Innsbruck, 141pp.

Tschaikner, A., Gärtner, G. and Kofler, W. 2008. Coelastrella aeroterrestrica sp. nov. (Chlorophyta, Scenedesmoideae) - a new, obviously often overlooked aeroterrestrial species. Algological Studies, 128(1): 11-20. https://doi.org/10.1127/18641318/2008/0128-0011

Tschaikner, A., Ingolić, E. and Gärtner, G. 2007. Observations in a new isolate of Coelastrella terrestris (Reisigl) Hegewald \& Hanagata (Chlorophyta, Scenedesmaceae) from alpine soil (Tyrol, Austria). Phyton - Annales Rei Botanicae, 46(2):237-245.

Uzunov, B. A., Stoyneva, M. P., Gärtner, G. and Koefler, W. 2008. First record of Coelastrella species (Chlorophyta: Scenedesmaceae) in Bulgaria. Berichte Des Naturwissenschaftlichen-Medizinischen Verein Innsbruck, 95: 27-34.

Vílchez, C., Forján, E., Cuaresma, M., Bédmar, F., Garbayo, I. and Vega, J. M. 2011. Marine carotenoids: Biological functions and commercial applications. Marine Drugs, 9: 319333. https://doi.org/10.3390/md9030319 


\section{A new record of Coelastrella terrestris}

Vorobyev, K., Andronov, E., Rautian, M., Skoblo, I., Migunova, A. and Kvitko, K. 2009. An atypical Chlorella symbiont from Paramecium bursaria. Protistology, 6: 39-44.

Wehr, J. D. and Sheath, R. G. 2003. Freshwater algae of North America: Ecology and classification. Elsevier Science, USA, 918pp. 
Bull. Iraq nat. Hist. Mus.

December, (2018) 15 (2): 153-161

$$
\text { تسجيل جديد للنوع }
$$

Coelastrella Terrestris (Reisigl) Hegewald \& N. Hanagata, 2002

(Sphaeropleales, Scenedesmaceae)

$$
\text { في العراق }
$$

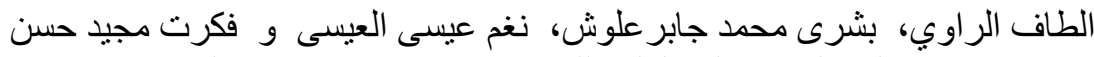

قسم علوم الحياة، كلية العلوم للبنات، جامعة بغداد، بغداد، العر اق تُ

تاريخ القبول: 2018/08/06

تاريخ الاستلام: 2018/06/01$$
\text { الخلاصة }
$$

اجريت هذه الدر اسة لتشخيص طحلب الجنس Coelastrella Chodat, 1922 المعند من عينات رواسب جمعت من نهر دجلة ضمن مدينة بغداد؛ عزل الطحلب وتم تنميته في

$$
\text { وسط جو } 10 \text { المحور. عن. }
$$

اظهرت الصفات المظهرية تحت المجر الضوئي بعض الخصائص التشخيصية لهذا الجنس، كثكلها البيضوي او الليموني والأجسام النشوية المرئية والبئية البلاستيدات الخضراء النياء

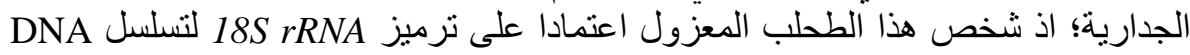

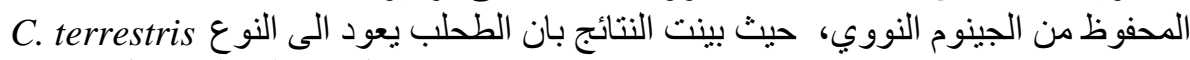
المeisigl) Hegewald \& N. Hanagata, 2002 العراق، وقد تم تسجيلها في NCBI تحت رقم الانضمام تصني (accession number) MH179121 